\title{
Early verb development in two French-speaking children ${ }^{*}$
}

\author{
Marianne Kilani-Schoch \\ Lausanne \\ mkilani@pop-server.unil.ch
}

\section{Introduction}

This paper deals with early verb development (e.g., person, tense) until the emergence of verbparadigms in two French-speaking children.

I will show the parallelism between the two children in the gradual building of paradigms, despite considerable differences in the rate of development. Individual differences on the other hand will bring me to reconsider the broad category of premorphological rote-learnt forms which already displays some patterning in one of the children's data.

\section{Description of verbs in the target language}

Grammatical categories of the French verb are person $\left(1^{\text {st }}, 2^{\text {nd }}, 3^{\text {rd }}\right)$ number (sg., pl.), tense, mood (indicative and imperative in early child language) and voice. However, in the spoken language, depending on the inflectional class (see below), these categories may not be expressed by suffixes, and verbal forms may be distinguished only by proclitic markers (je, $t u$, il, elle, ils, elles, on parle /parl/ 'I, you, he, she, we speak') and by auxiliaries (see below). In other words, in the productive microclass (and in some unproductive microclasses and paradigms), the 2 . $\mathrm{Pl}$. is often the only form having a verb suffix (e.g. parl-ez):

\begin{tabular}{|c|c|c|c|c|}
\hline \multirow{2}{*}{ 1. Pers. } & \multicolumn{2}{|c|}{ Present Indicative } & \multicolumn{2}{|c|}{ Imperative } \\
\hline & Singular & Plural & Singular & Plural \\
\hline $\begin{array}{l}\text { 1. Pers. } \\
\text { 2. Pers. } \\
\text { 3. Pers. }\end{array}$ & $\begin{array}{c}\text { parle /parl/ } \\
\text { parles /parl/ } \\
\text { parle /parl/ }\end{array}$ & $\begin{array}{c}\text { (parlons /parl-ōo/) } \\
\text { parlez /parl-e/ } \\
\text { parlent /parl/ }\end{array}$ & parle /parl/ & $\begin{array}{c}\text { parlons /parl-õ/ } \\
\text { parlez /parl-e/ }\end{array}$ \\
\hline
\end{tabular}

Homophonic forms in the categories used by the children in pre- and protomorphology are:

a) Pres.1.Sg, Pres.2.Sg, Pres.3.Sg, Pres.3.Pl, Imp.2.Sg: /parl/

b) Inf. parler, PP parlé: /parle/ (Pres.2.Pl \& Imp.2.Pl. parlez).

Non-finite categories (in child language) are Infinitive and PP. Infinitive is the citation form in French and is used in periphrastic constructions such as Compound Future and modal ones. Nonfinite PP is part of Compound Past (see below).

Within the category tense, spoken French has 4 compound forms (Compound Past, Compound Future, and Pluperfect, Past Future, both not expected in early child language), and two synthetic

\footnotetext{
* I would like to thank all the participants of the workshop and especially W.U. Dressler, D. Bittner, S. Klampfer and $\mathrm{C}$. Aguirre for their many helpful comments and suggestions.

1 On parle instead of nous parlons.
} 
forms less frequent in the input and rare in early child language: Imperfect (parl-ais) ${ }^{2}$ and Simple Future (parl( $e$ )-ra). The Simple Past (parl-a) is used only in fairy tales.

Compound past is auxiliary avoir 'have'/être 'be' + PP, elle a parlé 'she has spoken':

$\begin{array}{lcccc} & \text { Singular } & & \text { Plural } & \\ & \text { AUX } & \text { PP } & \text { AUX } & \text { PP } \\ \text { 1. Pers. } & \text { ai } / \mathrm{e} / & \text { parlé } / \text { parle/ } & \text { (avons } / a v \tilde{o} / \text { ) } & \text { parlé /parle/ } \\ \text { 2. Pers. } & \text { as } / \mathrm{a} / & & \text { avez } / \text { ave/ } & \\ \text { 3. Pers. } & \mathrm{a} / \mathrm{a} / & & \text { ont } / \tilde{\mathrm{o}} / & \end{array}$

Table 2. Compound past

Compound Future is semi-auxiliary aller 'go' + Inf: il va parler 'he will speak':

$\begin{array}{lcccc} & \text { Singular } & & \text { Plural } & \\ & \text { AUX } & \text { INF } & \text { semiAUX } & \text { INF } \\ \text { 1. Pers. } & \text { vais } / \mathrm{ve} / & \text { parler } / \text { parle/ } & \text { (allons } / \text { alö/) } & \text { parler } / \text { parle/ } \\ \text { 2. Pers. } & \text { vas } / \mathrm{va} / & & \text { allez } / \text { ale/ } & \\ \text { 3. Pers. } & \text { va } / \mathrm{va} / & & \text { vont } / \mathrm{vo} / & \end{array}$

Table 3. Compound Future

Isolated paradigms and unproductive classes have amplified bases and, depending on the inflectional class, vowel change, e.g.

\begin{tabular}{|c|c|c|c|c|c|c|}
\hline $\begin{array}{c}\text { partir } \\
\text { /partir/ } \\
\text { mordre } \\
\text { /mordr/ } \\
\text { venir } \\
\text { /vanir/ } \\
\text { recevoir } \\
\text { /rasavwar/ }\end{array}$ & $\begin{array}{l}\text { 'leave' } \\
\text { 'bite' } \\
\text { 'come' } \\
\text { 'become' }\end{array}$ & $\begin{array}{l}\text { part } \\
\text { /par/ } \\
\text { mord } \\
\text { /mor/ } \\
\text { vient } \\
\text { /vje// } \\
\text { reçoit } \\
\text { /rəswa/ }\end{array}$ & 1.PI. & $\begin{array}{l}\text { partent } \\
\text { /part/ } \\
\text { mordent } \\
\text { /mord/ } \\
\text { viennent } \\
\text { /vjen/ } \\
\text { reçoivent } \\
\text { /raswav/ } \\
\text { recevons } \\
\text { /rasavö/ }\end{array}$ & PP: & $\begin{array}{l}\text { parti } \\
\text { /parti/ } \\
\text { mordu } \\
\text { /mordy/ } \\
\text { venu } \\
\text { /vony/ } \\
\text { reçu } \\
\text { /rosy/ }\end{array}$ \\
\hline
\end{tabular}

\section{Data description}

My study is based on the corpora of two children from Lausanne (Switzerland): Sophie (SOP) (1;6.14 - 3;8.09, 60 recordings, 30 hours) and Emma (EMM) (1;4.13 - 2;11.3, 40 recordings, 19 hours) ${ }^{3}$. This study focuses on the data until the beginning of protomorphology (cf. below), i.e. until 2;0 in SOP's corpus (2978 utterances ${ }^{4}$ ), and 1;8 in EMM's corpus (1079 utterances) ${ }^{5}$. For the sake of comparison, however, some of the tables contain data of Emma until 2;0 (2684 utterances). Transcription and coding have been done according to CHILDES and quantitative analyses according to CLAN programs ${ }^{6}$.

2 Which corresponds to imperfective aspect opposed to perfective aspect of compound past.

3 The data of Emma are more limited than the data of Sophie. Emma has been recorded generally only twice a month and some of the recordings are very short (e.g. 1;6, 1;7, 2;0; at 1;7 diary notes are used to complement the recordings). This irregularity in the data of Emma is probably responsible for the greater heterogeneity of some of the findings on her language development.

4 To qualify as an utterance, a production has to include at least one meaningful unit resembling a French word in form and mcaning.

$5 \quad$ This corresponds roughly to the first 50 verb lemmas.

6 Thanks are due to Marc Xicoira and Martin Forst for technical help and to the University of Lausanne for financial support. 
SOP can be characterized as following a prosodic (formulaic strategy in Peters \& Menn 1993:745, cf. also Peters 1997: 159, Bates 1995) rather than a segmental strategy: she has massive phonological substitutions and a long and varied use of fillers (which disappear between $2 ; 6$ and $3 ; 0)$.

EMM, an early talker (MLU of 2.4 already at $1 ; 7$ and of 3.3 at $1 ; 10$ ), is rather (cf. 3.) a segmental child (cf. Peters \& Menn 1993) but favours also the imitative strategy (cf. several examples of rote-learned sequences in which she seems to play with her words and transform them in successive steps).

The phases of pre- and protomorphology correspond to the following time periods of the corpora:

SOP

$$
\begin{gathered}
1 ; 6.14-1 ; 10.4 \\
1 ; 11.19-2 ; 1.18^{7}
\end{gathered}
$$

EMM

$$
1 ; 4.13-1 ; 7.27
$$$$
1 ; 8.10-1 ; 10.29
$$

In SOP's corpus, protomorphology is demarcated by a syntactic spurt: 2-word utterances with verb reach almost $50 \%$ of the utterances with verb. There is also a first advance in article use and hence in the development of the noun phrase. First subject pronouns appear (cf. Kilani-Schoch \& Dressler 2000a, 2000b).

In EMM's corpus protomorphology starts when articles (74\% of prenominal contexts) and subject pronouns become frequent and fillers mostly preverbal. Syntax develops as well with first 3complement utterances, dislocated and cleft sentences.

\section{Predecessors of verbs in predicative function}

In both children there are some verbs already from the beginning of recordings (cf. 4.). Predecessors of verbs (more important in SOP than in EMM's corpus, $\mathrm{cf}$. the proportion of verbs in 4. below) nevertheless also occur, differently according to each child's language development.

There are more extragrammatical predecessors in SOP than in EMM's corpus, e.g.

a) fillers replacing main verbs, e.g 1;9.22 a là for viens là $/ v j \tilde{\varepsilon} \mathrm{la} /, 1 ; 11.29 / \mathrm{a} /$ pas for (je) sais pas /scpa/ '(I do) not (know)', 2;0.10 e plus for veux plus and modal/semi-auxiliary verbs before an infinitive (cf. Kilani-Schoch \& Dressler 2000b), e.g. 1;9.13 /atetir/ for (je veux) sortir /3ə vø sortir/, 1;10.16 anir ${ }^{8}$ for il va venir /il va vənir/ (but also a few examples in EMM's corpus, e.g. 1;5.13 è a sortir for il va sortir, 1;7.27 a venir for il va venir ${ }^{9}$ ),

b) onomatopoetic forms instead of verbs, e.g. 1;9.13 nan nan for mniam mniam ' $\mathrm{X}$ is eating', 1;9.22 boum le pam for (il) est tombé l'éléphant 'the elefant is fallen' (only nominal examples in EMM's corpus, e.g 1;5.28 pioupiou for oiseau 'bird', 1;6.25 wouwou for chien 'dog'). In the transition to protomorphology (cf. 2.) they are replaced by verb forms, e.g. poum becomes tombé/est tombé / $\varepsilon$ tõbe/ 'has fallen'.

Notice that root reduplications are almost inexistent in the corpus (cf. SOP pepleut for pleut 'it is raining', dedort for dort 'is sleeping'). It seems that French preference for monosyllabic

\footnotetext{
There is a transition phase between pre- and protomorphology in SOP's corpus.

This example is a lexical filler (cf. Kilani-Schoch \& Dressler 2000b).

Repetition of a first correct production.
} 
(morphological) verbs as well as the identity between the root and the inflectional form renders this kind of phono-morphological compensation ${ }^{10}$ unnecessary.

Both children have examples of (baby-talk) nouns without their governing semi-auxiliary, e.g. dodo for fait dodo 'sleeps' (at the very beginning in EMM's corpus), later with a prefixed filler, objects instead of their governing verbs, e.g. SOP 1;10.16 a po(r)te for ouvre la porte 'open the door', deictics (là 'there', ça 'this'), and adverbs denoting a process in predicative function, e.g. SOP 1;7.26; EMM 1;6.25 èto/tor, ator for encore /ãkor/ 'more, add', dehors /dəor/ 'outside'.

\section{Emergence of verb-forms}

\subsection{Quantitative data}

Verb spurt starts at 1;11.7 in Sophie's corpus and at 1;7 in EMM's corpus, i.e. at the turningpoint between pre- and protomorphology (see 2 and Tables $4 \mathrm{a}$ and $4 \mathrm{~b}$ ).

\begin{tabular}{|c|c|c|c|c|c|c|}
\hline SOP & & & & & & \\
\hline age & utterances & lemmas & lemmas $\%$ & types & tokens & tokens $\%$ \\
\hline $1 ; 6$ & 109 & 3 & $2.8 \%$ & 3 & 9 & $8.2 \%$ \\
\hline $1 ; 7$ & 225 & 8 & $3.6 \%$ & 8 & 17 & $7.5 \%$ \\
\hline $1 ; 8$ & 245 & 10 & $4 \%$ & 10 & 19 & $7.5 \%$ \\
\hline $1 ; 9$ & 606 & 27 & $4.4 \%$ & 33 & 95 & $15.7 \%$ \\
\hline $1 ; 10$ & 555 & 31 & $5.6 \%$ & 34 & 87 & $15.7 \%$ \\
\hline $1 ; 11.7$ & 176 & 16 & $9.1 \%$ & 16 & 39 & $22.1 \%$ \\
\hline PROTO & & & & & & 129 \\
\hline $1 ; 11$ end & 592 & 37 & $6.2 \%$ & 45 & 143 & $30.4 \%$ \\
\hline $2 ; 0$ & 470 & 49 & $10.4 \%$ & 63 & $1.8 \%$ \\
\hline
\end{tabular}

Table 4a. SOP: \% of verb lemmas, types \& tokens in relation to analyzed utterances

\begin{tabular}{|c|c|c|c|c|c|c|}
\hline EMM & & & & & & \\
\hline age & utterances & lemmas & lemmas \% & types & tokens & $\%$ \\
\hline $1 ; 4$ & 136 & 5 & $3.7 \%$ & 5 & 9 & $7 \%$ \\
\hline $1 ; 5$ & 287 & 21 & $7.3 \%$ & 24 & 72 & $25 \%$ \\
\hline $1 ; 6$ & 186 & 10 & $5.4 \%$ & 11 & 15 & $8 \%$ \\
\hline $1 ; 7$ & 133 & 21 & $15.8 \%$ & 24 & 53 & $39.8 \%$ \\
\hline $\begin{array}{c}(1 ; 7 \\
\text { rec.only) }\end{array}$ & (103) & (16) & $(15.5 \%)$ & (17) & (28) & $(27.2 \%)$ \\
\hline \multicolumn{7}{|l|}{ PROTO } \\
\hline $1 ; 8$ & 337 & 35 & $10.4 \%$ & 49 & 122 & $36 \%$ \\
\hline $1 ; 9$ & $37 !$ & 45 & $12.1 \%$ & 52 & 153 & $41 \%$ \\
\hline $1 ; 10$ & 631 & 54 & $8.5 \%$ & 84 & 273 & $43 \%$ \\
\hline $1 ; 11$ & 348 & 49 & $14.1 \%$ & 71 & 164 & $47 \%$ \\
\hline $2 ; 0$ & 255 & 30 & $11.8 \%$ & 41 & 86 & $34 \%$ \\
\hline
\end{tabular}

Table 4b. EMM: \% of verb lemmas, types $\&$ tokens in relation to analyzcd utterances

Categories used before the beginning of protomorphology (i.e. SOP 1;6-1;11.7, 266 verb tokens, EMM 1;4 - 1;7, 149 tokens) are Present Indicative Singular, Imperative, Infinitive ${ }^{12}$, Past

I0 The notion is due to W.U. Dressler.

11 Frozen lorms (and fillers) are excluded, see Tables $8 \mathrm{a}$ and $8 \mathrm{~b}$.

12 These 3 categories are the most important categories in spoken French and several verbs have no other forms used (Blanche-Benveniste \& Adam 1999). 
Participle, and lately Compound Past, plus for EMM isolated occurrence of Compound Future and Imperfect ${ }^{13}$.

\begin{tabular}{|c|c|c|c|c|c|c|c|}
\hline SOP & & & & & & & \\
\hline age & Pres.Ind.Sg $^{14}$ & IMP & INF & PP & C.Past & C.Fut. & Pres.Passive \\
\hline $1 ; 6$ & $2 / 6$ & & & & & & \\
\hline $1 ; 7$ & $3 / 7$ & & $2 / 3$ & $1 / 2$ & & & \\
\hline $1 ; 8$ & $5 / 10$ & $1 / 4$ & $2 / 4$ & $1 / 1$ & & & \\
\hline $1 ; 9$ & $18 / 47$ & $3 / 4$ & $8 / 23$ & $2 / 11$ & & & \\
\hline $1 ; 10$ & $12 / 22$ & $4 / 8$ & $8 / 15$ & $6 / 19$ & $2 / 2$ & & \\
\hline $1 ; 11.7$ & $6 / 11$ & $1 / 3$ & $5 / 16$ & $3 / 3$ & $2 / 2$ & & \\
\hline PROTO & & & & & & & \\
\hline $1 ; 11$ end & $19 / 52$ & $2 / 5$ & $11 / 24$ & $6 / 9$ & $6 / 21$ & & \\
\hline $2 ; 0$ & $24 / 56$ & $5 / 17$ & $14 / 37$ & $7 / 13$ & $9 / 13$ & $1 / 1$ & $2 / 2$ \\
\hline
\end{tabular}

Table 5. SOP: Emergence of verb categories (lemmas/tokens) until protomorphology 15,

\begin{tabular}{|c|c|c|c|c|c|c|c|c|}
\hline EMM & & & & & & & & \\
\hline age & Pres.Ind.Sg & Pres.3P & IMP & INF & PP & Imperfect & S.Past & S.Fut. \\
\hline $1 ; 4$ & $? 1 / 1$ & & $1 / 1$ & $2 / 4$ & $? 1 / 3$ & & & \\
\hline $1 ; 5$ & $7 / 14$ & & $4 / 12$ & $13 / 32$ & $3 / 10$ & & & \\
\hline $1 ; 6$ & $6 / 7$ & & 0 & $3 / 3$ & $1 / 3$ & & & \\
\hline $1 ; 7$ & $10 / 20$ & & $4 / 6$ & $11 / 17$ & $1 / 4$ & $1 / 1$ & & \\
\hline PROTO & & & & & & & & \\
\hline $1 ; 8$ & $18 / 51$ & $1 / 1$ & $4 / 11$ & $16 / 28$ & $4 / 8$ & $1 / 1$ & $1 / 2$ & \\
\hline $1 ; 9$ & $\begin{array}{c}16 / 55 \\
+1 / 1 \\
\text { Pres.1.Sg }\end{array}$ & $2 / 7$ & $3 / 19$ & $20 / 50$ & $6 / 9$ & $1 / 1$ & & $1 / 1$ \\
& & & & & & & \\
\hline
\end{tabular}

Table 6a. EMM: Emergence of synthetic verb categories (lemmas/tokens) until protomorphology

\begin{tabular}{|c|c|c|c|}
\hline EMM & & & \\
\hline age & Comp.Fut. & Comp.Past & Pres.Passive \\
\hline $1 ; 4$ & & & \\
\hline $1 ; 5$ & & & $1 / 3$ \\
\hline $1 ; 6$ & & & \\
\hline $1 ; 7$ & $1 / 1$ & $1 / 1$ & \\
\hline PROTO & & & $1 / 1$ \\
\hline $1 ; 8$ & $2 / 2$ & $\begin{array}{c}6 / 9 \\
(1 \mathrm{token}=1 . \mathrm{sg})\end{array}$ & \\
\hline $1 ; 9$ & $3 / 3$ & $5 / 6$ & \\
\hline
\end{tabular}

Table 6b. EMM: Emergence of periphrastic verb categories (lemmas/tokens) before protomorphology

In imitation.

14 SOP and EMM (one isolated example in EMM's corpus at 1;9 however) do not have yet person distinction but recall that in French conjugation only suppletive verbs mark first person distinctly from 2./3. person, cf. 1 .

15 In all tables direct imitations are included: in my corpora (and especially in Emma's corpus), a verb form may alternatively appear as spontaneous or imitated without any apparent systematicity such as, e.g. imitated form first. Imitations thus deserve a specific study. Proportions are given in Tables $8 \mathrm{a}$ and $8 \mathrm{~b}$. Ambiguities are listed separately (see Table 10a and 10b).

16 Compound Past and Compound Future forms are counted as single verb-forms of these categories. 


\begin{tabular}{|c|c|c|c|c|c|c|}
\hline & \multicolumn{3}{|c|}{ SOP } & \multicolumn{3}{c|}{ EMM } \\
\hline & lemmas & tokens & $\%$ & lemmas & tokens & $\%$ \\
\hline Pres.Ind.Sg. & 32 & 103 & $46.2 \%$ & 16 & 42 & $29.4 \%$ \\
\hline Infinitive & 18 & 61 & $27.4 \%$ & 22 & 56 & $39.2 \%$ \\
\hline Imperative & 6 & 19 & $8.5 \%$ & 5 & 19 & $13.3 \%$ \\
\hline Past participle & 9 & 36 & $16.1 \%$ & 4 & 20 & $14 \%$ \\
\hline Comp.Past & 3 & 4 & $1.8 \%$ & 1 & 1 & $0.7 \%$ \\
\hline Periphrastic Passive & 2 & 2 & $0.9 \%$ & 1 & 3 & $2 \%$ \\
\hline Comp.Future & 0 & 0 & 0 & 1 & 1 & $0.7 \%$ \\
\hline Imperfect & 0 & 0 & 0 & 1 & 1 & $0.7 \%$ \\
\hline Total & 51 & $\mathbf{2 2 3}$ & & 37 & $\mathbf{1 4 3}$ & \\
\hline
\end{tabular}

Table 7. Summary of verb categories before protomorphology (ambiguities excluded)

The verb categories occurring before protomorphology are quite similar in both children. However, the two children differ strikingly as far as the number of Pres.Ind.Sg. vs. Infinitive forms is concerned: whereas SOP has a preference for Pres.Ind.Sg. forms over Infinitives, EMM has the opposite preference for Infinitives over Pres.Ind.Sg. forms. Put differently, EMM seems to have a preference for morphological forms while SOP seems to rather prefer root-forms (cf. 4.2.). The comparison between all morphological forms (Inf. + all PP, included PP of periphrastic verb-forms) and all root-forms (Pres.Ind. + Imp) does not contradict this finding: SOP has still more root-forms $(54.7 \%)$ and EMM more morphological forms $(57.3 \%)$.

At the onset of protomorphology, verb categories in Emma's language are more numerous and varied than in Sophie's language at the same age. This underlies the different rates of development of the two children. In EMM's corpus, plural verb forms occur from 1;8 on ${ }^{17}$, Present 1 st $\mathrm{Sg}$. from 1;9, Imperfect from 1;11. Notice in addition an isolated occurrence of Simple Past $(1 ; 8)$ and one of Simple Future $(1 ; 9)$.

Although as said above EMM favours an imitative strategy, verb imitations are not more frequent in EMM's corpus than in SOP's corpus during these early periods:

\begin{tabular}{|c|c|c|c|c|c|c|c|}
\hline SOP & & & & & & & \\
\hline age & Pres.Ind.Sg & IMP & INF & $\mathrm{PP}$ & Comp.Past & Total & $\%$ tokens \\
\hline $1 ; 6$ & $2 / 2$ & & & & & $2 / 2$ & $22 \%$ \\
\hline $1 ; 7$ & $2 / 2$ & & $1 / 1$ & & & $2 / 3$ & $17.6 \%$ \\
\hline $1 ; 8$ & $4 / 4$ & & $2 / 2$ & & & $6 / 6$ & $31.6 \%$ \\
\hline $1 ; 9$ & $10 / 14$ & $2 / 2$ & $3 / 5$ & $2 / 5$ & & $20 / 26$ & $27.4 \%$ \\
\hline $1 ; 10$ & $2 / 2$ & & $2 / 4$ & $1 / 2$ & $1 / 1$ (passive) & $6 / 8$ & $9.2 \%$ \\
\hline $1 ; 11.7$ & $2 / 2$ & & $2 / 2$ & $1 / 1$ & $1 / 1$ & $6 / 6$ & $15.4 \%$ \\
\hline \multicolumn{8}{|l|}{ PROTO } \\
\hline $1 ; 11$ end & $8 / 12$ & & & $3 / 4$ & $1 / 1$ & $12 / 18$ & $14 \%$ \\
\hline $2 ; 0$ & $5 / 7$ & $1 / 1$ & $2 / 2$ & $3 / 3$ & $1 / 1$ & $12 / 14$ & $9.8 \%$ \\
\hline
\end{tabular}

Table 8a. SOP: Imitations (percentages in relation to the number of verb tokens)

17 Notice however that they are not productive before 2;2: the corpus shows either formulaic plural verb lorms (partez "go", attendez "wait") or the 3rd Present Pl. form of être 'be' sont 'are' and other verb forms with family resemblance (font 'do', ont 'have'). 


\begin{tabular}{|c|c|c|c|c|c|c|c|c|c|}
\hline EMM & & & & & & & & & \\
\hline age & Pres.Ind.Sg & IMP & INF & PP & Comp.Past & Comp.Fut. & Imperfect & total & $\%$ tokens \\
\hline $1 ; 4$ & & & $2 / 2$ & $2 / 2$ & & & & $2 / 4$ & $44.4 \%$ \\
\hline $1 ; 5$ & $2 / 2$ & $2 / 2$ & $4 / 6$ & $2 / 2$ & & & & $10 / 12$ & $16.7 \%$ \\
\hline $1 ; 6$ & $4 / 4$ & & $1 / 1$ & & & & & $5 / 5$ & $33.3 \%$ \\
\hline $1 ; 7$ & $3 / 3$ & & & & & & $1 / 1$ & $4 / 4$ & $14.3 \%$ \\
\hline PROTO & & & & & & & & & \\
\hline $1 ; 8$ & $5 / 12$ & $1 / 1$ & $5 / 5$ & $3 / 4$ & $\begin{array}{c}1 / 1 \\
+1 / 1 \text { passive }\end{array}$ & & & $18 / 24$ & $19.7 \%$ \\
\hline $1 ; 9$ & $5 / 8$ & & $4 / 6$ & $1 / 1$ & $1 / 1$ & $1 / 1$ & $1 / 1$ & $13 / 18$ & $11.8 \%$ \\
\hline
\end{tabular}

Table 8b. EMM: Imitations (percentages in relation to the number of verb tokens)

The difference shows up rather in the number of frozen forms in protomorphology:

\begin{tabular}{|c|c|c|c|c|}
\hline Premorphology & types & tokens & utterances & $\%$ \\
\hline SOP $(1 ; 6-1 ; 11.7)$ & 7 & 64 & 1916 & $3.3 \%$ \\
\hline EMM $(1 ; 4-1 ; 7)$ & 5 & 29 & 845 & $3.4 \%$ \\
\hline
\end{tabular}

Table 9a. Premorphology: Frozen forms (percentages in relation to the number of analyzed utterances)

\begin{tabular}{|c|c|c|c|c|}
\hline $\begin{array}{c}\text { Protomorpholoy } \\
\text { (first 2 months) }\end{array}$ & types & tokens & utterances & $\%$ \\
\hline SOP $(1 ; 11-2 ; 0)$ & 7 & 30 & 1062 & $2.8 \%$ \\
\hline EMM $(1 ; 8-1 ; 9)$ & 9 & 68 & 708 & $9.6 \%$ \\
\hline
\end{tabular}

Table 9b. Protomorphology (first 2 months): Frozen forms (percentages in relation to the number of analyzed utterances)

No formal, class shift or agreement error occur yet in the corpus of EMM (cf. 7.). In SOP's corpus there are 3 possible number agreement errors at 1;8 and 1;9. More important in her corpus are the ambiguities between AUX (avoir, être) of, e.g., Compound Past, semiAUX (avoir, as in avoir peur 'be afraid') and fillers (cf. Table 10a): in SOP's corpus Present Sg. forms of avoir and etre are difficult to identify due to the massive use of fillers (e.g. /a, , , e/ peur 'is afraid', /a,ə, \&/ beau for est beau 'is beautiful', /a, ə, $\varepsilon /$ là/ dur, /apabe/ for CP est tombé or PP tombé, /atate/ for CP a sauté or PP sauté, etc.:

\begin{tabular}{|c|c|}
\hline SOP & ambiguities \\
\hline $1 ; 6$ & $3\left(\mathrm{SAUX}^{\wedge} \mathrm{FILL}\right)$ \\
\hline $1 ; 7$ & $5\left(\mathrm{SAUX}^{\wedge}\right.$ FILL $)$ \\
\hline $1 ; 8$ & 0 \\
\hline $1 ; 9$ & 10 (Ind.Pres. ${ }^{\wedge}$ FILL, Ind.Pres. $\left.{ }^{\wedge} \operatorname{Imp}, \mathrm{PP}^{\wedge} \operatorname{Inf}\right)$ \\
\hline $1 ; 10$ & 21 (SAUX $^{\wedge}$ FILL, CP$^{\wedge}$ FILL, Inf.^PP, $\left.N^{\wedge} \mathrm{V}\right)$ \\
\hline $1 ; 11.7$ & 4 (Inf.^PP, Passive ${ }^{\wedge}$ FILL) \\
\hline Total & 43 \\
\hline \multicolumn{2}{|l|}{ PROTO } \\
\hline $1 ; 11$ end & $18\left(\operatorname{Inf}^{\wedge} \mathrm{PP}\right.$, Ind.Pres ${ }^{\wedge} \mathrm{Imp}$, SAUX^FILL) \\
\hline $2 ; 0$ & 6 (Ind.Pres ${ }^{\wedge}$ FILL, $\left.\mathrm{PP}^{\wedge} \mathrm{INF}\right)$ \\
\hline
\end{tabular}

\begin{tabular}{|c|c|}
\hline EMM & ambiguities \\
\hline \multicolumn{2}{|l|}{$1 ; 4$} \\
\hline $1 ; 5$ & $1\left(\mathrm{PP}^{\wedge} \mathrm{INF}\right)$ \\
\hline $1 ; 6$ & 2 (IMP^Pres.Sg, DEICT^Ind.Pres.) \\
\hline $1 ; 7$ & 3 (Ind.Pres ${ }^{\wedge}$ FILL) \\
\hline Total & 6 \\
\hline \multicolumn{2}{|l|}{ PROTO } \\
\hline $1 ; 8$ & $2\left(\mathrm{Inf}^{\wedge} \mathrm{PP}, \mathrm{AUX} \mathrm{X}^{\wedge} \mathrm{FILL}\right)$ \\
\hline $1 ; 9$ & $1\left(\mathrm{~V}^{\wedge} \mathrm{CONJ}\right)$ \\
\hline
\end{tabular}

Table 10a. SOP: Ambiguities Table 10b. EMM: Ambiguities

\subsection{Distinctions among rote-learnt forms}

First verb-forms of the French corpora can be divided into 3 major types (plus intermediate forms): 
a) verb-forms corresponding to roots, i.e. without any inflection, e.g.

SOP, 1;6 3.Pres.Sg. dort 'sleeps', 3.Pres.Sg. pleut 'rains'

EMM, 1;5 Imp. donne 'give', 1;6 3.Pres.Sg aime 'likes'.

b) Inflected verb-forms (not before 1;8 in SOP), e.g.

SOP 1;8 Inf donner 'give', PP cassé 'broken';

EMM 1;4 Inf sortir 'go out', 1;5 PP parti 'gone';

c) frozen/formulaic forms, i.e., in terminological difference to e.g. Pine \& Lieven 1993, a subset of rote-learnt, contextually/situationally bound, morphologically non-distinctive forms. A frozen form frequently occurs in one single pattern, but the constituent verb never in any other pattern; the contextual meaning of this pattern may not be clearly linked to the lexical meaning of the verb, especially if it is idiomatic, especially regulative, phatic, e.g. French ça marche 'I agree', German passt 'fits', which can be simply substituted by 'OK, fine'. A frozen-form candidate is unlikely to be frozen, if the constituent verb emerges earlier as single verb than the frozen-form candidate, but there are exceptions: English to go as a main verb may emerge earlier than the adult amalgam gonna. Moreover, a frozen form generally constitutes a single-element utterance: if it combines with other elements, it is on a way of "defrozeness". In our corpora a frozen form is used repeteadly and is not limited to isolated examples (cf. SOP ça marche 'it works' not a likely candidate for frozen form). We distinguish:

i. amalgams which are always frozen forms, i.e. adult multiword combinations treated as one unanalyzed word by the child, thus morphosemantically and morphotactically opaque (even fused), e.g. SOP \& EMM /alcla/ and variants for il/elle est là 'he/she is there', /teje/ and variants for ça y est; SOP /ewawa/ and variants for on va voir 'we will see', SOP à boire 'I want to drink';

ii. regulative or phatic forms corresponding to a single verb-form or to a verb-form plus proclitic: SOP attends 'wait', EMM tu sais 'you know', EMM ça va 'it's ok'. Such forms correspond to adult automatic speech and could be substituted easily by a pragmatically synonymous form of very different structure, e.g. attends! --> une minute!, tu sais --> eh! (?), ça va -->OK ${ }^{18}$.

iii. imitated forms, i.e. repetitions of the adult target in the next turn.

The difference between a), b) and c) is gradual. Segmentation is probably the most important difference between frozen forms and other verb-forms. Whereas root-forms and inflected forms have been segmented from the rest of the phonological word, frozen forms represent generally a whole utterance or turn and may be memorized as such. But basically these first verb productions are all rote-learnt (cf. MacWhinney 1978): in the first 2 months of recording (before 1;8 SOP and 1;6 EMM), all verbs have one single form and later on at most 2 forms (see below), in other words they are invariable and unanalysed. In Tomasello's approach this early verb development is said to be lexically-based (Tomasello 1992, Akhtar \& Tomasello 1997, Lieven 1998, Pine, Lieven \& Rowland 1998).

Things may be further refined however. We have, indeed, noticed already some pattern in the repartition of verb-categories among the two children (Table 5), i.e. SOP's preference for rootforms opposed to EMM's preference for inflected forms.

18 As mentioned by Blanche-Benveniste \& Adam (1999: 90), it is sometimes difficult to distinguish between a phatic and a plain use of verb forms. 
Moreover, whereas nothing relevant seems to be found in root-forms and frozen forms, another pattern emerges from inflected forms. Several measures show that EMM has a strong preference for 1st macroclass (i.e. microclasses 1 and 2) types (and tokens) of Infinitive (see Table 11) ${ }^{19}$ :

\begin{tabular}{|l|c|c|c|c|c|c|c|c|}
\hline & \multicolumn{3}{|c|}{ SOP } & $1 ; 8-1 ; 11.7$ & \multicolumn{4}{c|}{ EMM } \\
\hline & types & $\%$ & tokens & $\%$ & types & $\%$ & tokens & $\%$ \\
\hline I. macroclass & 10 & $56 \%$ & 29 & $48 \%$ & 19 & $83 \%$ & 30 & $65 \%$ \\
\hline other classes & 8 & $44 \%$ & 31 & $52 \%$ & 4 & $17 \%$ & 16 & $35 \%$ \\
\hline
\end{tabular}

Table 11. Bare Infinitives

The difference between Sophie and Emma's Infinitives does not appear in the input: 1st macroclass types are preferred in Emma (65\% vs. 35\%) and Sophie's input (60\% vs. 40\%). The opposite preference holds for tokens but the proportions are less similar in the two inputs: whereas Sophie's input clearly favours non-1 ${ }^{\text {st }}$ macroclass tokens $(69 \%$ vs. $31 \%)$, Emma's input has an almost equal proportion of the 2 classes. It appears that several tokens are repetitions of the child's production and that, when putting them aside, there is a majority of non- ${ }^{\text {st }}$ macroclass tokens $(51 \%$ vs. $47 \%$ ) (the percentages of Sophie's input almost do not change with the same deduction: $70 \%$ vs. $30 \%$ ). Non- ${ }^{\text {st }}$ macroclass finite forms are also dominant.

\begin{tabular}{|l|c|c|c|c|}
\hline & SOP & input & EMM & input \\
\hline & types & tokens & types & tokens \\
\hline I. macroclass & $60 \%$ & $31 \%$ & $65 \%$ & $47 \%$ \\
\hline other classes & $40 \%$ & $69 \%$ & $35 \%$ & $51 \%$ \\
\hline
\end{tabular}

Table 12. Infinitives in the input

The preference for $1^{\text {st }}$ macroclass types and tokens of Infinitives in Emma's corpus is confirmed by the examination of the first 50 lemmas produced by the children: of the 14 infinitives occurring in Sophie's corpus $7(50 \%)$ belong to the $1^{\text {st }}$ macroclass and 7 to other classes, i.e. there is no apparent selectivity with regard to the inflectional classes; in the corpus of Emma, 13 of the 16 infinitives produced belong to the $1^{\text {st }}$ macroclass $(81 \%)$.

The same result obtains again with all types of inflected forms (PP, Compound Past, Infinitive, Compound Future) of the first 50 lemmas:

SOP: $54 \%$ of $1^{\text {st }}$ macroclass lemmas $-46 \%$ of others

EMM: $70 \%$ of $1^{\text {st }}$ macroclass lemmas $-30 \%$ of others.

EMM appears thus to be more of a morphotactic child than SOP. This difference fits with the pattern of verb-categories mentioned above (4.1.) and with morphosemantic aspects (see KilaniSchoch \& Dressler 2000c). With such morphologically conditioned selection, EMM's premorphological phase can be said to show a greater variety of patterns than SOP's premorphological phase, i.e. there is more (pre)morphology in the former.

19 Finite forms in general do not display the same distribution: in both corpora non-1 st macroclass tokens or lemmas are dominant. Recall however that Present Indicative Sg. (and 3d Pl. in the $1^{\text {st }}$ macroclass and in some verbs of the $2^{\text {nd }}$ macroclass) has no inflectional marking and corresponds to the simple base. 


\section{Syntactic usages}

Forms a), b) and c) occur first (SOP until 1;9.13, EMM until 1;5.3) as single-element utterances. In EMM's corpus between $1 ; 4.13$ and 1;7.27, i.e. before the first mini-paradigms (see 6), examples of verbs used in various utterances (i.e. with different word-types) are limited to the volitive veux + infinitive (11 tokens/143 verb-forms), e.g.

(1) 1;5.13 a veux aller 'I want to go',

(2) 1;8 veux voir les souris 'I want to see the mice'.

At 1;8.10 however, one finds besides

(3) a veux t' assar for je veux m'asseoir 'I want to sit down'

(4) s'est assis à côté 'sat down nearby',

and besides

(5) /fa/ mett(re) for va/veux mettre 'will put /wants to put'

a structure with proclitic object

(6) on le met là 'we put it there'

and an interrogative one

(7) t' as mis où?? 'where did you put';

also

(8) manger salade 'eat salad',

and the same verb in the only example of a cleft construction with a relative clause

(9) è Maman \# qui mange 'it's Mum who is eating'.

Sophie's data before the emergence of the mini-paradigms are richer due to the greater length of this period ( 6 months $)^{20}$. It is by $1 ; 11$ (i.e. at the beginning of protomorphology and one month before the first mini-paradigms) that 2-element structures with a verbal predicate plus a nominal argument (subject or object) show a spurt ${ }^{21}$ and reach almost $50 \%$ of the utterances with verb ${ }^{22}$. The preferred syntactic schema seems to be based on a basic prosodic pattern unstressed Filler + I or 2 syllable(s) with final stress (see Kilani-Schoch \& Dressler 2000b), e.g. /ado/ for F(il y en a) $\operatorname{deux} / \mathrm{d} \varnothing /$ '(there are) two', /ədodo/ for $\mathrm{F}$ (il fait) dodo '(he) sleeps'. It is a reduplication of this basic prosodic schema: $\mathrm{F} 1+\mathrm{X} F 2+\mathrm{Y}$ when $\mathrm{X}, \mathrm{Y}$ are monosyllabic, e.g.

(10) (without verb) $1 ; 11.29$ a bain a chat for $\mathrm{F}($ le) bain $\mathrm{F}($ le) chat = ?le chat va dans le bain 'the cat is going in the bathtub',

(11) $1 ; 11.29 / 2 ; 0.10$ /ase aso/ for $\mathrm{F}$ (ren)versé $\mathrm{F}$ (le) seau 'turned (the) bucket over',

(12) a boit un bib for $\mathrm{F}($ il $)$ boit un biberon 'he is drinking a bottle'.

When $\mathrm{X}$ or $\mathrm{Y}$ or both are dissyllabic the prenominal filler may be deleted, e.g.

(13) $1 ; 11.19$ a papé chat for $\mathrm{F}\left(j^{\prime}\right)$ ai tapé (le) chat '(I) slaped (the) cat',

(14) 1;11.29/ع tjef/ bébé for $\mathrm{F}(j e)$ cherche $\mathrm{F}(l e)$ bébé vs.

(15) $1 ; 11.29$ è che $(r)$ che a vache for $\mathrm{F}(j e)$ cherche $\mathrm{F}($ la $)$ vache, or

(16) /pam atitir/ for $\mathrm{F}\left(l^{\prime}\right)$ éléphant $\mathrm{F}$ (veut) sortir '(the) elefant (wants to) go out'.

20) And to a greater number of recordings, see notc 1 .

21 In the meantime the most frequent 2-element structure is Neg pas+V (e.g. out of 212 -element structures there are 12 occurrences of the type Negation $+X / 270$ utterances at $1 ; 9.13$ ).

$229 / 40$ utterances with verb $(22,5 \%)$ at $1 ; 11.7>29 / 61$ at $1 ; 11.19$. 
The strongest tendency however seems

a) that the verb stands in the initial position independently of the syntactic status (subject or object) of the following noun, e.g.

(17) 1;11.29 embête SUBJ Maman 'Mum bothers',

(18) 1;11.19 veux mettre OBJ bébé 'want to put (the) baby',

and in the first lexical position after F1 if there is a filler, e.g.

(19) 1;11.7 a taté SUBJ chein for (il) est caché (le) chien 'the dog is hidden',

b) to have a preverbal filler or no filler at all (i.e. not a prenominal filler only), compare (17), (18) with (19) and (20):

(20) 1;11.19 e chercher OBJ /munu/ for (je) cherche $(l ')$ ours 'I'm looking for the bear'.

In other words these structures are syntactically rather than only prosodically determined. What they highlight is however a very restricted syntactic diversity and the absence of syntactic function for inflectional morphology. Bare infinitives are indeed often in optional variation with finite forms (see 6.).

This picture is typical for a transition between the premorphological phase of rote-learning and creative protomorphology. Thus it is not surprising that first examples of frozen forms combined with a new and free argument occur in the same period, e.g.

(21) 1;11.19 /evavar/ agnée for $\mathrm{F}($ on) va voir araignée 'we will see (the) spider',

(22) 1;11.29 e tou(r)ne a passe for on tourne $\mathrm{F}($ la $)$ page 'we/let's turn the page'.

\section{Emergence of mini-paradigms}

\subsection{Criteria}

How do children start to form paradigms at all, and what evidence do we have? Since the occurrence of more than one verb form of a verb does not constitute in itself evidence for paradigm formation (Cf. Tomasello 1992, Behrens 1999), methodological prerequisites for assessing morphological relatedness between distinct verb forms of the same lemma in the data are necessary (cf. Allen 1996). We propose five criteria for establishing the onset of a paradigm, i.e. spontaneous production (not imitative), spontaneous production (not formulaic), articulatory accuracy, use in contrasting contexts, recurrence (cf. Kilani-Schoch \& Dressler 2000c), e.g., in

SOP

(23) chercher 'look for': 1;11.19 a $\int \varepsilon \int \mathrm{e} /$ for Inf. chercher / $\mathrm{\varepsilon} \mathrm{er} \mathrm{e} /$ for ?je cherche - a cherche for Pres.Ind.sg. cherche / $\int \mathrm{erg} /$ for ?je cherche (same forms at $1 ; 11.29$ and 2;0.22)

Inf. and Pres.Ind.Sg seem to be optional variants, whereas in

(24) mettre 'put': 2;0.22 Pres.Ind.sg. i met /me/ tatalon for je mets pantalon 'I put trousers on' Comp.Past 3rd sg. a mis /ami/ do for a mis de l'eau 'has put some water' - a mettre a papo for mettre le chapeau 'put the hat on'

the forms represent a true mini-paradigm.

Compare also in the corpus of 
EMM

(25) appuyer 'press': 1;7.27 sequence: apini [//] apie [/] apie [/] apie a Papa [//] apie Papa [//] apier Papa. (apini = ? blend of finir: Comp.Past 3d sg. a fini /a fini/ 'ended' or appuyer, Imp. appuie, apie $=\operatorname{Imp}$ appuie, apier $=$ Inf. appuyer $)$

with a true mini-paradigm:

(26) mettre 'put': 1;8.10 Pres.Ind.sg on le met là 'we put it there' - Aux/Mod+Inf.: /fa/ mett(re) for va/veux mettre 'will put/wants to put' - Comp.Past 3rd sg. $t^{\prime}$ as mis où ? 'where did you put'.

Hence we define the first "true", but still very incomplete, thus minimal, paradigms as nonisolated sets of minimally 3 accurate and distinct inflectional forms of the same verbal lexeme produced spontaneously in contrasting contexts.

This leads to an analysis of the development of paradigms as a gradual process with different building steps.

\subsection{Mini-paradigms: steps of development}

First two forms of a verb-lemma appear at $1 ; 8$ for SOP, at 1;5 for EMM. First mini-paradigms have been considered to occur not earlier than three months later, i.e. at the end of $2 ; 0$ for SOP, and at $1 ; 8$ for EMM. In the meantime several mini-paradigm candidates (pairs or triplex of verbforms) occur:

SOP $(1 ; 8-2 ; 0.22)$ : 16 lemmas

Unclear: 9 , context-bound: 8 , isolated: 4 , imitations: 3 , formulaic: $2^{2.3}$

$\operatorname{EMM}(1 ; 5-1 ; 8.10): 7$

Unclear: 4, isolated: 2 , context-bound: 2 , imitations: 2 , formulaic: $1 / 2^{24}$.

On the basis of the criteria mentioned above, we distinguish three steps in the emergence of paradigms.

Step a. A very first step consists in approximations of different verb-forms of verb types, e.g. $\operatorname{SOP}(1 ; 8-1 ; 9 / 1 ; 10)$

(27) laver 'wash' 1;7.26 ?Pres.Ind.Sg /awa/ for ?lave /lav/ - 1;9.13 ?Inf /œve/ for laver /lave/

$\operatorname{EMM}(1 ; 5 .-1 ; 6)$

(28) donner 'give' 1;5.3 ?Inf /tate/ for ?donner/done/ - 1;5.3 Imp donne /don/.

In this first step the forms are also rather isolated and do not recur before at least two months.

This preliminary step is followed by a second pre-paradigm step:

$\underline{\text { Step } b .}$. The different verb forms of lemmas which occur in this second step before the first miniparadigms, are either isolated forms, imitated forms, formulaic forms, context-bound forms or optional variants connected by some irregular (not rule-governed) morphotactic similarity, e.g.

SOP $(1 ; 9-2 ; 0)$

(29) SOP essayer 'try' 2;0.10 Imp Maman essaie /Ese/ 'Mum try', next utt. Inf: non là , Maman essayer/escje/

EMM (1;7 - 1;8), e.g. (25) above.

23. The numbers correspond to verb-lemmas. There is overlapping of criteria for several verbs.

24 All numbers are tokens. 
Step c. After a slow extension of verb forms for some verb lemmas, first true mini-paradigms appear. A time interval and a sufficient number of "preparadigms", i.e. verb-specific inflected forms, seem thus to be needed by the children before they can recognize the morphological principle of related form and meaning (plus distinctivity) and can actively use formal marking of verb inflection. On the basis of the criteria presented above, we can conclude that there is no mini-paradigm before the occurrence of 3 forms of a verb ${ }^{25}$. In the two corpora, the first evidence for a true mini-paradigm is given by the occurrence of a non- ${ }^{\text {st }}$ macroclass verb with 3 contrasting forms along with other two-member paradigms in the same month ${ }^{26}$ :

$\operatorname{SOP}(2 ; 0.22)$

(30) mettre 'put': Pres.Ind. 3rd Sg. met /me/ - Comp.Past 3d.Sg. a mis /a mi/ - Inf. mett(re) /mعt/

(31) partir 'leave': 1;10.16 onw. Comp.Past 3rd.Sg. est parti $/ \varepsilon$ parti/ - 2;0.22 Pres.Ind. 3rd Sg. part /par/

(32) mordre 'bite': 2;0.22 Pres.Ind. 3d Sg. mord /mor/ - Comp.Past 3d Sg. a mordu /a mordy/

(33) sortir 'go out': 2;0.10 Pres.Ind.Sg. sort/sor/ - 2;0.22 Inf. sortir/sortir/.

The following mini-paradigm candidates do not match at least one of the criteria:

[cacher (unclear), casser@IMI, chercher (unclear and context-bound), essayer (optional var.), laver (unclear), regarder 'look' (context-bound), sauter (unclear), tomber (unclear), venir (context-bound), voir (frozen), s'asseoir (unclear), boire formulaic, unclear, PP isolated, partir (unclear)].

EMM $(1 ; 8.10)$

(34) mettre 'put': Pres.Ind.2/3Sg mets /me/ - Inf. mettre /met/ - Comp.Past 2Sg. as mis /a mi/

(35) manger 'eat': 1;8.10 Pres.Ind.3d.Sg. mange /mãz/- Inf. manger /mãze/.

(36) sortir 'go out': 1;8.24 Inf. sortir/sortir/ - Comp.Past 3d.Sg a sorti /a sorti/

vs.

[donner (optional variants), marcher (formulaic), casser (unclear), attacher (unclear and @IMI), appuyer (unclear/sequence), partir (sequence)].

In both children the first mini-paradigm with three contrasting forms coincides with the beginning of protomorphology. Moreover, in both children it is the verb mettre (cf. Guillaume 1927, Martinot 1998). Frequency of mettre in the input does not account for this finding: indeed the results of verb (lemma) frequency in SOP and EMM's inputs rank mettre respectively in the seventh and fifth position only ${ }^{27}$ :

input SOP: être, faire, AUXlavoir, aller, AUXlaller, vouloir, mettre

input EMM: être, faire, AUXlavoir, AUXIaller, mettre, aller, vouloir.

In addition to structural reasons (mettre is more "regular" than the other verbs with high frequency), semantic and pragmatic factors must be considered: mettre is a "light" verb which indicates only the moving of an object by an agent without specifying manner and location and it is an important verb in situations of play. In addition this finding can be attributed to the

25 Cf. in different context and for a different purpose Pine \& Lieven (1993: 558): three instances of a construction are needed for qualifying as constructed.

26 On the parallel establishment of recurrent morphosemantic oppositions, see Kilani-Schoch \& Dressler $2000 \mathrm{c}$.

27 In the GARS's corpus of spoken French (cf. Blanche-Benveniste \& Adam 1999: 101), mettre is not among the most frequent verbs either (less than 1000 occurrences) but is morphologically differentiated ( 21 categories used). 
characteristics of the input language (system-adequacy). The first conjugation class - the most frequent and the only productive verb type in French - has more homophony in the categories used by the little child than the other verbs. This homophony is even increased in filler children like SOP and - to a lesser extent EMM -, where filler + stem ending in /e/ may correspond to Infinitive, Compound Past, Past Participle or Compound Future. Hence the child has first more difficulty in forming 3-member paradigms with distinct members of the 1 st conjugation class than with members of other classes.

\section{Morphological substitutions}

\subsection{Root-infinitives}

By far the most frequent morphological substitutions in the period considered and in the whole corpora are root-infinitives:

SOP 1;6 - 1;11: 76 / 374 verb-forms (20\%), 1;6-2;0:113/512 (22\%), Input: infinitives represent $17 \%$ of all verb-forms,

EMM 1;4-1;7: $49 / 122$ verb-forms (40\%), 1;4-1;8: 73/245 (30\%), Input : $21 \%$.

Root infinitives may result from omission of the auxiliary or modal verb, e.g. 0aux/0mod + Inf (root infinitives):

SOP

(37) 1;9 /atetir əwã/ for (il) veut sortir (l')éléphant 'the elefant wants to go out',

(38) 1;11 là Papa gicler (= là Papa va gicler) 'squirt with water'

or - less frequently - occur instead of a finite form, e.g.

SOP

(39) $1 ; 9.13$ /açaçe/ for chercher $=(j e)$ cherche /3ə $\int \operatorname{erg} /$ ' (I) am looking for',

\section{EMM}

(40) $1 ; 8$ faire bobo là $(=$ ça fait bobo là) 'is hurting there'.

Root infinitives however are more of a syntactic than of a morphological type of production (cf. Phillips 1995): among other factors they may be attributed to the saliency of the infinitive in syntactic structures such as modal structures (see Wijnen, Kempen \& Gillis 2000) and to the ambiguity of the preverbal position (several clitic options appear before an infinitive, e.g., semiauxiliary $v a$, prepositions $\grave{a}$, de, which cannot be predicted by the form of the immediately following verb). In languages such as French and German, the homophony of infinitive with PP and plural forms also favours their occurrence.

\subsection{Analogical formations and overgeneralisations}

All examples of analogical formations or overgeneralisations occur significantly after the first mini-paradigms (cf. 8.). For lack of space we will consider class shift only ${ }^{28}$.

28 Category shifts are rare (around 5 per child) and not clearly of an analogical nature. My formulae of proportional analogy takes the most similar verbs as model but the actual model may be also another verb or an abstract pattern (minor rule). 
SOP: between $2 ; 2.0$ and $2 ; 7.18: 5$ types/10 tokens $+? 1$

EMM: between 1;9 and 2;9: 2 types/5 tokens.

Class shifts are mainly overgeneralisations of $1^{\text {st }}$ macroclass Infinitive, e.g. SOP and EMM Inf. metter for mettre 'put' ${ }^{29}$ (cf. 6.2.), SOP Inf. descender for descendre 'go down', SOP Inf. pompirer for remplir 'fill', EMM Inf. sorter for sortir 'go out', SOP Comp.Past a voulé for a voulu 'wanted', Comp.Past $a v e ́$ for $a v u$ 'has seen', i.e. overgeneralisations based on the productive class. But there are also overgeneralizations within 2. macroclass, e.g. SOP and EMM Inf. tiendre $/ \mathrm{tj} \widetilde{\mathrm{edr}} /(=$


Comp.Past a prendu /a prãdy/ for a pris /a pri/ 'has held', i.e. not based on a productive model. The latter must be analysed as rime analogies based on phonological and prosodical similarities. The child has related verb forms of isolated paradigms (Inf. tenir 'hold' and prendre 'take') to sets of whole paradigm riming verbs, i.e. to verbs having the same phonological form except the initial sequence, e.g. rendre, (en)tendre, descendre, (dé)fendre, vendre, pendre. The verb prendre is an isolated paradigm of this set, but it rimes with its members in a great part of the paradigm (not in Pres.Pl, Imperfect and Past Participle). What seems most important here is the rime in the base form (Pres.Sg.) prend and in the base derived Inf. prendre. The childish Comp.Past $a$ prend $u$, based on the rime between rend and prend, is derived by a minor rule coresponding to the proportional analogy: rend: prend $=$ rendu: $x$. The overgeneralisation tiendre is based on a rime with the set of verbs peindre, teindre, atteindre, éteindre, plaindre, craindre. In the adult language the base forms with stressed nasal vowels rime: tient /tjẽ / rimes with teint $/ \mathrm{t} \tilde{\mathrm{e}} /$, éteint letê/, peint /pẽ/. The riming part of the paradigm is however more limited than in the case of prendre since it applies only in the Pres.Sg and in the Simple Future (tiendrai, peindrai). The proportional analogy seems to be: éteint: tient $=$ éteindre: $x$.

These examples demonstrate that no inflectional imperialism (cf. Slobin 1968) occurs in my corpora.

\section{Conclusion}

\subsection{Early verb development and pre- and protomorphology}

First, in premorphology, the emergence of verbs is lexical (steps 1 and 2). Premorphology is the phase in which no system of grammatical morphology has dissociated from a general cognitive system. Morphological operations are extragrammatical ones or rote-learnt precursors of later grammatical rules (cf. Dressler \& Karpf 1995, Dressler 1997, Dziubalska-Kolaczyk 1997, KilaniSchoch \& Dressler 2000b).

In protomorphology the system of morphological grammar and of its subsystems starts to develop without reaching the status of modules (components) or submodules (subcomponents). The paradigm formation process starts to emerge: at the beginning it is limited to some lemmas (overlap of steps 2 and 3), and there is no across-the-board generalization. However it soon develops into an increasing number of new mini-paradigms:

29 A similar example is mentioned by Clark (1985: 703). 


\begin{tabular}{|c|c|c|c|c|c|c|}
\hline SOP & $\begin{array}{c}\text { new mini-paradigms (2- } \\
\text { members or more) } \\
\text { per total of lemmas /month }\end{array}$ & $\%$ & $\begin{array}{c}\text { number of } \\
\text { mini-p/month }\end{array}$ & $\begin{array}{c}\text { paradigm } \\
\text { values } \\
\mathrm{P}(\mathrm{utt})\end{array}$ & $\mathrm{P}(\mathrm{lcm})$ & $\mathrm{P}(\mathrm{tok})$ \\
\hline $2 ; 0$ & $4 / 49$ & $11.4 \%$ & 4 & $0.9 \%$ & $8.2 \%$ & $2.8 \%$ \\
\hline $2 ; 1$ & $9 / 52$ & $19.1 \%$ & 11 & $1.6 \%$ & $21.2 \%$ & $17.5 \%$ \\
\hline $2 ; 2$ & $11-12 / 60$ & $20 \%$ & 22 & $2.5 \%$ & $36.7 \%$ & $5.7 \%$ \\
\hline $2 ; 3$ & $14 / 56$ & $25 \%$ & 27 & $3.6 \%$ & $48.2 \%$ & $10.5 \%$ \\
\hline $2 ; 4$ & $14 / 80$ & $17.5 \%$ & 33 & $3 \%$ & $41.3 \%$ & $6.1 \%$ \\
\hline
\end{tabular}

Table 13a. New mini-paradigms in SOP's corpus

\begin{tabular}{|c|c|c|c|c|c|c|}
\hline EMM & & & & & & \\
\hline $1 ; 8$ & $7 / 35$ & $20 \%$ & 7 & $2.1 \%$ & $20 \%$ & $5.7 \%$ \\
\hline $1 ; 9$ & $6 / 45$ & $13.3 \%$ & 9 & $2.4 \%$ & $20 \%$ & $6 \%$ \\
\hline $1 ; 10$ & $14 / 54$ & $25.9 \%$ & 21 & $3.3 \%$ & $39 \%$ & $7.7 \%$ \\
\hline $1 ; 11$ & $6 / 49$ & $12.2 \%$ & 12 & $3.4 \%$ & $24.4 \%$ & $7.3 \%$ \\
\hline $2 ; 0$ & $3 / 30$ & $10 \%$ & 10 & $3.9 \%$ & $33.3 \%$ & $11.6 \%$ \\
\hline
\end{tabular}

Table 13b. New mini-paradigms in EMM's corpus

Consider also the occurrence of 3-member paradigms:

SOP 2;1: 2 3 (sauter 'jump', partir 'leave', ?faire 'do')

2;2: 4 (partir, mettre 'put', faire, voir 'see')

2;3: 4 (mettre, faire, voir, aller 'go')

EMM 1;9: 3 (pleurer 'cry', montrer 'show', tomber 'fall', voir 'see')

1;10: 7 (manger 'eat', finir 'end', mettre 'put', voir 'see', faire 'do', avoir 'have', être 'be')

1;11: 7 (jouer 'play', donner 'give', monter 'go up', entendre 'hear', faire 'do', aller 'go', voir'see').

This development will lead to morphological productivity in modularized morphology ${ }^{31}$ (cf. Kilani-Schoch et al. 1997, Kilani-Schoch \& Dressler 2000b).

The identification, during protomorphology, of morphosemantic oppositions and the establisment of mini-paradigms seems to be the precondition for identifying analogical relationships and for extending them in terms of proportional analogies. Creative morphological patterns, e.g., overgeneralizations, indeed follow two months later (from $2 ; 2$ on in SOP's corpus, from $1 ; 10$ on in EMM's corpus, see Appendix).

These observations, together with EMM's morphotactic selectivity which seems to imply that some general grouping of verbs has been already made by the child, indicate that some generalization has taken place, i.e. in protomorphology the children have started to understand the morphological principle of relating forms and meanings in regular ways.

We thus rather adopt an intermediate position with regard to the lexically specific vs. verbgeneral account of verb emergence (cf. Tomasello 1992, Akhtar \& Tomasello 1997, Lieven 1998, Pine et al. 1998, Maratsos 1998, Behrens 1999) and see the same pattern of gradual and

30) Since the number of mini-paradigms found in one corpus may depend on sample size, Sabine Klampler (1his volume) has proposed different paradigm values as index for the paradigm formation capacity of a child. They are calculated by dividing the number of mini-paradigms by the number of analyzed utterances ( $\mathrm{P}(\mathrm{utt}))$, verb lemmas $(\mathrm{P}(\mathrm{Vlem}))$ and verb tokens $(\mathrm{P}(\mathrm{Vtok}))$ per month and thus give a sample-size independent value enabling the comparison of mini-paradigms across different corpora.

31 Modularized morphology contains the nucleus of mature morphological grammar. Subsystems of verb and noun inflection are distinguished. 
progressive (inflectional) development as observed by Allen (1998), Ninio (1999) and Mueller Gathercole et al. (1999).

\subsection{Typological characteristics}

A first general property of French which is weakly inflecting and approaches the isolating type is that many verb-forms do not involve any morphological operation. With regard to this criterion one may expect

a) that non-inflected (verbal root) forms, i.e. Pres.Ind.Sg or Imp, should appear first and earlier than inflected categories. This prediction is born out for SOP's data where inflected forms occur at 1;8 only, but not in the case of EMM. As said above, EMM favours inflected forms which are used from the very beginning. Individual differences hence go beyond typological adequacy;

a') that two related predictions are that inflected forms such as plural forms should emerge later than in non-isolating languages, e.g. in stronger inflecting languages (cf. Kilani-Schoch et al. 1997) and that periphrastic verb-forms should emerge earlier than in non-isolating languages;

a") that periphrastic Past and Future should emerge before their synthetic competitors. This is amply documented by any study on acquisition of French;

b) that nouns and verbs emerge simultaneously, particularly that earliest verb forms emerge as early as first nouns (but individual strategies put a strong limitation to this prediction, cf. Braunwald 1995). In other words, French morphology should not stimulate children to acquire nouns or verbs earlier than the other category. Indeed this expectation is born out in my data;

b') that earliest verb forms emerge earlier than in non-isolating, stronger inflecting languages (but that the whole verbal system becomes is acquired later than in these languages);

c) that the non-differenciation of singular and plural forms (in the 1. productive microclass) should ease reference to plural subjects. However instances of plural meaning (i.e. contextual meaning) of verb forms in this early stage are almost inexistent;

d) that tense distinctions emerge before person and number distinctions. This holds true for my data (see Tables 5 and 6). As far as tense is concerned, however, considering that early Past Participle and Compound Past are mostly used with telic lemmata (Vendler 1967) (e.g. casser 'break', fermer 'close', tomber 'fall', partir 'leave', finir 'end'), this first distinction between finite verb-forms (let alone Imp) could be rather characterized in terms of aspect rather than in terms of tense (but cf. Shirai \& Andersen 1995). It seems nevertheless that both children extend Compound Past to activity (SOP: 2;2.13 a léché 'licked', EMM 1;8.24 a pleuré 'cried') and stative verbs (SOP: 1;11.29 and EMM 1;8.10 $t^{\prime}$ as $v u$ 'you have seen') before they introduce first person distinction, i.e. the distinction between 1. and 3. person (1.Pres.Sg. = SOP 2;5, EMM 1;9) in suppletive verbs; Comp.Fut. - Present distinction is frequent at 2;4 in SOP, at 1;10 in EMM; as to number distinction, 3.Pres.Pl. is frequent later than first non-present tenses and 1.Sg. (in addition to $3 . \mathrm{Sg}$.): SOP at $2 ; 7, \mathrm{EMM}$ at $2 ; 2$.

More system-specific but still typologically adequate is, e.g., the homophony between Inf. and PP in the productive 1. microclass. From this homophony one could make the hypotheses

e) that Inf. and PP would emerge earlier and with higher frequency than in languages not having this homophony (cf. Kilani-Schoch et al. 1997); but see the individual difference between SOP and EMM (Table 5); 
f) that periphrastic verb-forms should emerge earlier than in isolating languages and others not having this homophony (cf. Kilani-Schoch et al. 1997);

g) that there should be analogical PP forms based on Inf. (less probably vice versa, because Inf. is less marked than PP) in unproductive microclasses and isolated paradigms. However there is only one instance in the corpus of SOP: 2;5 PQP avait mettre for avait mis 'has put ${ }^{32}$;

h) that since in French the only productive microclass has also the highest lemma frequency and is the default class, it is easily predictable that morphological substitutions occur exclusively in unproductive microclasses and isolated paradigms. My data are in accordance with this prediction (see 7.2.).

i) that since aspectual distinctions are not encoded separately from tense in French and are tied to the opposition between periphrastic and synthetic tense, aspectual distinctions obviously depend on the mastery of the respective tense subsystem, i.e. the opposition between imparfait (Imperfect as in Latin and in the other Romance languages) and passé composé (Compound Past).

\section{References}

Akhtar, N. \& M. Tomasello. 1997. Young children's productivity with word order and verb morphology. Developmental Psychology 33, 6, 952-965.

Allen, S.1996. Assessing productivity in acquisition data from polysynthetic languages: an Inuktitut example. Paper presented at the 7th International Congress for the Study of Child Language. Istanbul.

Allen, S. 1998. Categories within the verb category: learning the causative in Inuktitut. Linguistics 36,4, 633-677.

Bates, E., P.S. Dale \& D. Thal. 1995. Individual differences and their implications for theories of language development. In P. Fletcher \& B. MacWhinney (eds.), The Handbook of Child Language. Oxford: Blackwell, pp. 96-151.

Behrens, Heike. 1999. Was macht Verben zu einer besonderen Kategorie im Spracherwerb? In J. Meibauer \& M. Rothweiler (eds.), Das Lexikon im Spracherwerb. Tübingen: Francke, pp.32-50.

Blanche-Benveniste, C. \& J.-P. Adam. 1999. La conjugaison des verbes: virtuelle, attestée, défective. Recherches sur le français parlé, 15, 87-112.

Braunwald, S.R. 1995. Differences in the acquisition of early verbs: evidence from diary data from sisters. In M. Tomasello \& W.E. Merriman. Beyond Names for Things. Hillsdale: Erlbaum, pp. 81-111.

Clark, E.V. 1985. The acquisition of Romance, with special reference to French. In D. I. Slobin (ed.), The Crosslinguistic Study of Language Acquisition. Vol. 1. Hillsdale: Erlbaum, pp. 687-782.

Dressler, W. U. (ed.) 1997. Studies in Pre- and Protomorphology. Vienna: Austrian Academy of Sciences.

Dressler, W. U. \& A. Karpf 1995. The theoretical relevance of pre- and protomorphology in language acquisition. Yearbook of Morphology 1994, 99-122.

Dziubalska-Kolaczyk, K. (ed.). 1997. Pre- and Protomorphology in Language Acquisition. Papers and Studies in Contrastive Linguistics 33.

Guillaume, P. 1927. Le développement des éléments formels dans le langage de l'enfant. Journal de Psychologie 24, 203-229.

Kilani-Schoch, M., A. De Marco, A. Christofidou, M. Vassilakou, R. Vollmann \& W. U. Dressler, 1997. On the demarcation of phases in early morphology acquisition in four languages. In K. DziubalskaKolaczyk (ed.), Pre- and Protomorphology in Language Acquisition. Papers and Studies in Contrastive Linguistics 33, 15-32.

\footnotetext{
32 The analogical Inf. metter 'put' also occurs in the same recording session.
} 
Kilani-Schoch, M. \& W. U. Dressler. 2000a. Are precursors of morphemes relevant for morphological theory? In M. Pöchtrager et al. (eds.), Morphological Analysis in Comparison. Amsterdam: Benjamins, pp. 89-111.

Kilani-Schoch, M. \& W. U. Dressler. 2000b. Filler + Infinitive and Pre- \& Protomorphology demarcation in a French acquisition corpus. Journal of Psycholinguistic Research. To appear.

Kilani-Schoch, M. \& W.U. Dressler. 2000c. The emergence of verb paradigms in two French corpora as an illustration of general problems of pre- and protomorphology. To appear.

Lieven, E. V. M. (ed.) 1998. Developing a Verb Category: Cross-Linguistic Perspectives. Linguistics 364.

MacWhinney, B. 1978. The acquisition of Morphonology. Monographs of the Society for Research in Child Development, vol. 43, 1-2.

Maratsos, M. 1998. Commentary. In Lieven, E. V.M. (ed.) 1998. Developing a Verb Category: CrossLinguistic Perspectives. Linguistics 36-4, 831-846.

Martinot, Claire. 1998. Développement de la construction argumentale de trois verbes essentiels. Langue française 118, 61-83.

Mueller Gathercole, V., E. Sebastian \& P. Soto. 1999. The early acquisition of Spanish verbal morphology: across-the board or piece-meal knowledge? In M. Vihman (ed.), First steps in morphological and syntactic development: cross-linguistic evidence. International Journal of Bilingualism 3, 2, 133-182.

Ninio, A. 1999. Model Learning in syntactic developement: intransitive verbs. In M. Vihman (ed.), First steps in morphological and syntactic development: cross-linguistic evidence. International Journal of Bilingualism 3, 2, 111-132.

Peters, Ann M. 1997. Language typology, prosody and the acquisition of grammatical morphemes. In Dan I. Slobin (ed.), The Crosslinguistic Study of Language Acquisition, vol.5. Mahwah: Erlbaum, pp. 135-197.

Peters, A. M. and L. Menn 1993. False starts and filler syllables: ways to learn grammatical morphemes. Language 69, 4, 742-777.

Phillips, C. 1995. Syntax at age 2: crosslinguistic differences. MIT Working Papers in Linguistics 26, 325382.

Pine, J. M. \& E. V. M. Lieven. 1993. Reanalysing rote-learned phrases: individual differences in the transition to multi-word speech. Journal of Child Language 20, 551-571.

Pine, J. M., E. V. M. Lieven \& C. F. Rowland. 1998. Comparing different models of the development of the English verb category. In Lieven, E. V. M. (ed.) 1998. Developing a Verb Category: CrossLinguistic Perspectives. Linguistics 36-4, 831-846.

Shirai, Y. \& R. W. Andersen. 1995. The acquisition of tense-aspect morphology: a prototype account. Language $71,4,743-762$.

Slobin, D. 1968. Early grammatical development in several languages, with special attention to Soviet research. Working Paper 11, Language-Behavior Res. Lab., Univ. Calif., Berkeley.

Stenzel, A. 1997. Die Entwicklung der syntaktischen Kategorien Nomen und Verb bei ein- und zweisprachigen Kindern. Tübingen: Narr.

Tomasello, M. 1992. First Verbs. Cambridge: Cambridge University Press.

Vendler, Z. 1967. Linguistics in Philosophy. Ithaca: Cornell University Press.

Wijnen, F., M. Kempen \& S. Gillis. 2000. Root infinitives in Dutch early child language: an effect of input. Journal of Child Language. To appear. 


\section{APPENDIX}

\section{Analogical formations}

SOP

2;2.0 Inf. metter for mettre 'to put' (after 1st macroclass) Other (similar) forms of the same lemma: Inf. mettre /met/ from 2;0.22 onwards.

2;2.0 Inf. apir /apir/ for appuyer /apuije/ 'to press' (after $2^{\text {nd }}$ macroclass ??, or phonological motivation). Other forms: 2;1.8 pie for appuyer, 2;1.18 Imp. /api/ appuie .

2;2.13 Past Participle a prendu for a pris 'took' (after $8 . \mathrm{mc}$ of $2^{\text {nd }}$ macroclass, e.g. rendre, tendre, vendre, descendre, etc.). Other forms of the same lemma or of lemmas of corresponding microclass: $2 ; 0.22$ Inf. ?prendre, 1;11.9 Comp.Past a perdu 'has lost', 2;0.22 PP mordu 'bitten', 2;1.8 Comp.Past as entendu 'has heard'

2;3.22 Inf. descender for descendre 'go down' (after $1^{\text {st }}$ macroclass). Other forms: 2;0.22 Pres.Ind.Sg. descend, Inf. ?descendre.

2;4.22 Inf. p(r)omèner/promene/ for promener/promne/ 'walk' (after $1^{\text {st }}$ microclass of $1^{\text {st }}$ macroclass), the morphonological rule of mid-vowel alternation does not apply.

2;5.3. Inf. pompirer for remplir (after $1^{\text {st }}$ macroclass). No other lemma from the same microclass. Correct occurrences at $2 ; 6.25,2 ; 7.18$.

$2 ; 5.14,2 ; 5.27,2 ; 7.4,2 ; 7.18$ Inf. metter for mettre (see above)

2,5.27 Comp.Past a voulé Maman for a voulu 'wanted': (after $1^{\text {st }}$ macroclass or or Filler + Impf., cf. next utterance: Impf. voulait Maman 'wanted'.

2;6.25 Comp.Past $a$ vé for $a v u$ 'has seen' (after $1^{\text {st }}$ macroclass). Other forms: 2;3.9 onw.: $a v u$.

2;7.18 Inf. tiendre for tenir 'hold' (after class $2,9 . \mathrm{mc}$ of $2^{\text {nd }}$ macroclass, e.g. peindre, éteindre, craindre). Other forms: 2;5.3 Inf. tenir, 2;2.27 Pres.Ind.Sg. tient 'holds', 2;2.27 Inf. éteindre 'turn off', 2;7.18 Pres.Ind.Sg t' éteins 'you turn off'.

\section{EMM}

1;10 Inf. sorter for sortir 'go out' (after $1^{\text {st }}$ microclass) (2 tokens). Other forms: from 1;4 onw. Inf. sortir. 2:2 Inf. metter for mettre 'put' (after $1^{\text {st }}$ microclass) ( 3 tokens). Other forms: $1 ; 8.10 \mathrm{Inf}$. mettre /met/, 2;0.17 Impf mettais. 